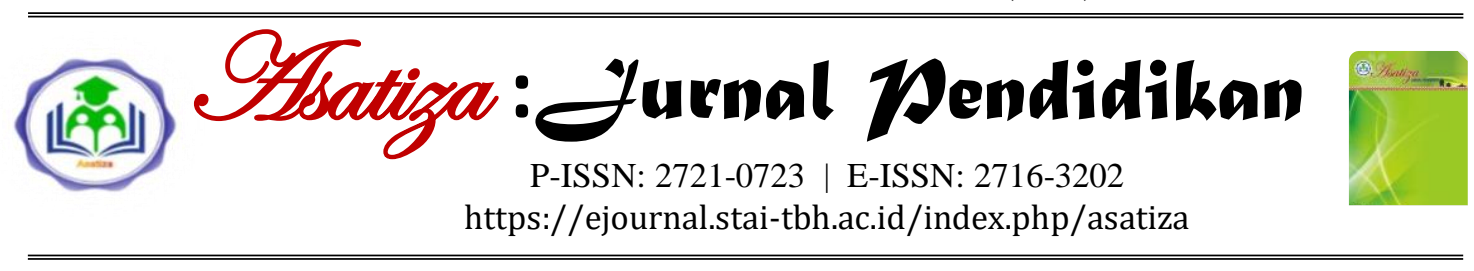

\title{
Studi Kebijakan mengenai Gerakan Literasi Sekolah
}

\begin{tabular}{|c|c|}
\hline \multicolumn{2}{|c|}{ 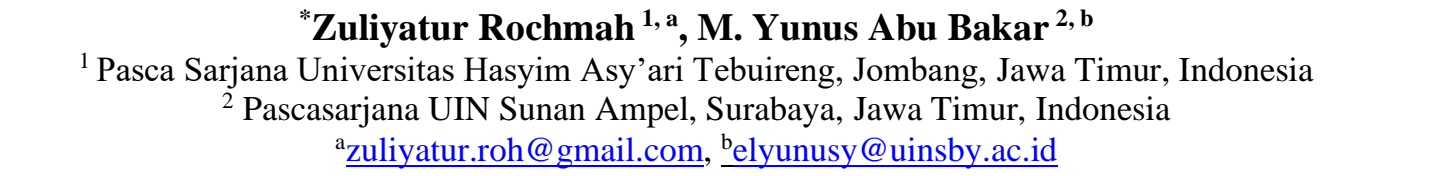 } \\
\hline & \multirow{13}{*}{  } \\
\hline & \\
\hline Histori Artikel: & \\
\hline : 11/01/2021 & \\
\hline & \\
\hline & \\
\hline oltkan : $2 J$ & \\
\hline $\begin{array}{l}\mathbf{A} \\
S c\end{array}$ & \\
\hline kolah & \\
\hline & \\
\hline & \\
\hline *Correspondence & \\
\hline & \\
\hline
\end{tabular}

Cara mensitasi artikel:

Rochmah, Z., \& Bakar, M. Y. A. (2021). Studi kebijakan mengenai gerakan literasi sekolah. Asatiza:

Jurnal Pendidikan, 2(2), 110-115. https://doi.org/10.46963/asatiza.v2i2.288

\section{PENDAHULUAN}

Terbitnya Permendikbud tentang penumbuhan budi pekerti tidak lepas dari konteks global. Sejak tahun 2000,
Indonesia telah berpartisipasi dalam survei PISA. Di dalam setiap survei tiga tahunan tersebut posisi Indonesia selalu berada di posisi terbawah, jauh di bawah negara 
tetangga seperti Malaysia, Singapura, dan Vietnam. Menurut survei PISA 2015 yang diumumkan pada tahun 2016, Indonesia berada pada peringkat ke-64 dari 72 negara yang disurvei (Antoro, 2017, hlm. 9).

Gerakan Literasi Sekolah' dirumuskan dalam rapat yang digelar pada akhir tahun 2015. Prosesnya tidak memakan waktu lama. Semua peserta memahami bahwa Mendikbud Anies Baswedan menjadikan 'gerakan' sebagai ciri pembangunan pendidikan. (Antoro, 2017, hlm. 22) Hal itu tertuang dalam Permendikbud Nomor 23 Tahun 2015 yang menjadi dasar GLS, di mana Pasal 2 ayat (c) menyebutkan bahwa 'Penumbuhan Budi Pekerti bertujuan untuk menjadikan pendidikan sebagai gerakan yang melibatkan pemerintah, pemerintah daerah, masyarakat, dan keluarga.(Kemendikbud, 2015).

Setelah muncul permendikbud tentang penumbuhan budi pekerti tersebut, sesuai dengan kebijakan otonomi daerah dan kondisi literasi di tiap daerah berbedabeda, maka Ditjen Dikdasmen (Direktorat jenderal Pendidikan Dasar dan Menengah) dituntut untuk membuat buku panduan literasi sekolah sebagai payung hukum dan penjelasan detail mengenai gerakan literasi sekolah. Pada akhirnya program gerakan literasi sekolah memiliki buku panduan umum dan buku panduan khusus. Panduan umum bergaris besar petunjuk pelaksanaan literasi sekolah, sedangkan panduan khusus membahas petunjuk teknis penyelenggaraan literasi di tiap satuan pendidikan (Antoro, 2017, hlm. 16).

\section{METODE}

Metode dalam penelitian ini adalah riset pustaka (library research) yang memanfaatkan sumber perpustakaan untuk memperoleh data penelitiannya. Tegasnya riset pustaka (library research) membatasi hanya pada bahan-bahan koleksi perpustakaan saja tanpa memerlukan riset lapangan (field research) (Zed, 2008, hlm. 1). Untuk memperoleh data penulis menggunakan sumber yang terdapat di perpustakaan seperti buku, jurnal, dan internet.

\section{HASIL DAN PEMBAHASAN \\ Definisi Gerakan Literasi Sekolah}

Gerakan literasi sekolah merupakan sebuah upaya yang dilakukan secara menyeluruh dan berkelanjutan untuk menjadikan sekolah sebagai organisasi pembelajaran yang warganya literat sepanjang hayat melalui pelibatan publik. Sekolah sebagai organisasi pembelajaran yang literat adalah sekolah yang menyenangkan dan ramah anak di mana semua warganya menunjukkan empati, kepedulian, semangat ingin tahu dan cinta pengetahuan, cakap berkomunikasi dan dapat berkontribusi kepada lingkungan sosialnya. Pelibatan publik adalah peran serta warga sekolah (guru, kepala sekolah, peserta didik, orang tua, tenaga kependidikan, pengawas sekolah dan Komite Sekolah) akademisi, dunia usaha dan industri dan pemangku kepentingan di bawah koordinasi Direktorat Jenderal Pendasmen Kemendikbud (Fath et al., 2018, hlm. 344).

Secara tradisional, literasi dipandang sebagai kemampuan membaca dan menulis. Pengertian literasi selanjutnya berkembang menjadi 
kemampuan membaca, menulis, berbicara dan menyimak. Jika diselisik secara komprehensif, perubahan konsepsi literasi terjadi dalam lima generasi. Pada masa perkembangan awal, literasi didefinisikan sebagai kemampuan untuk menggunakan bahasa dan gambar dalam bentuk yang kaya dan beragam untuk membaca, menulis, mendengarkan, berbicara, melihat, menyajikan dan berpikir kritis tentang ide-ide. Perkembangan kedua, literasi sebagai praktik sosial dan budaya dipandang sebagai prestasi kognitif yang bebas konteks.

Dalam generasi ketiga, literasi diperluas ke dalam beberapa jenis elemen literasi, seperti visual, auditori dan spasial daripada kata-kata yang tertulis. Dalam generasi keempat, literasi dipandang sebagai konstruksi sosial dan tidak pernah netral. Teks yang ditulis seorang peneliti telah dibentuk berdasarkan posisi mereka (di mana mereka berada dan di mana mereka berdiri, serta bagaimana posisi ini memungkinkan mereka untuk melihat dan tidak melihat). Generasi kelima, untuk menjadi literat pada abad informasi ini berarti harus mampu untuk terlibat dalam berbagai praktik literasi, serta mampu menggambarkan berbagai perangkat keterampilan literasi dalam keberagaman domain literasi. Istilah literasi generasi kelima ini dikenal dengan istilah multiliterasi (Sari, 2018).

\section{Tujuan Gerakan Literasi Sekolah}

Tujuan umum mengenai adanya gerakan literasi sekolah adalah:

Menjadikan sekolah sebagai organisasi pembelajaran berbudaya literasi

Membangun warga sekolah yang literat dalam hal baca tulis, numerisasi, sains, digital, finansial, budaya dan kewarganegaraan. (Kemendikbud Satgas Gerakan Literasi Sekolah, 2019, hlm. 5)

Gerakan literasi sekolah juga memiliki tujuan khusus yakni:

Menumbuhkembangkan budaya literasi membaca dan menulis peserta didik di sekolah.

Meningkatkan kapasitas warga dan lingkungan sekolah agar literat.

Menjadikan sekolah sebagai taman belajar yang menyenangkan dan ramah anak agar warga sekolah mampu mengelola pengetahuan.

Menjaga

keberlanjutan pembelajaran dengan menghadirkan beragam buku bacaan dan mewadahi berbagai strategi membaca (Fath et al., 2018, hlm. 345).

\section{Landasan Gerakan Literasi Sekolah}

Adanya gerakan literasi sekolah berlandaskan pada landasan filosofis dan landasan hukum.

\section{Landasan filosofis}

Dalam sumpah pemuda butir ketiga menyatakan bahwa kalimat "menjunjung bahasa persatuan bahasa Indonesia" memiliki makna pengakuan terhadap keberadaan ratusan bahasa daerah yang memiliki hak hidup dan peluang penggunaan bahasa asing sesuai dengan keperluannya. Butir tersebut menegaskan peningnya pembelajaran berbahasa dalam pendidikan nasional. Berikut merupakan konvensi terkait literasi:

1) Konvensi PBB tentang Hak Anak tahun 1989 mengenai pentingnya penggunaan bahasa ibu. Indonesia yang memiliki beragam suku bangsa, khususnya mikrokultur-mikrokultur tertentu perlu difasilitasi dengan 
bahasa ibu saat mereka memasuki pendidikan dasar kelas rendah yakni kelas I, II, III.

2) Konversi PBB di Praha tahun 2003 mengenai kecakapan literasi dasar dan kecakapan perpustakaan yang efektif merupakan kunci bagi masyarakat yang literat dalam menghadapi derasnya arus informasi teknologi. Lima komponen esensial literasi informasi adalah basic literacy, library literacy, media literacy, tecnologi literacy dan visual literacy. (Kemendikbud Satgas Gerakan Literasi Sekolah, 2019).

\section{Landasan Hukum}

Undang-Undang Dasar 1945, Pasal 31, Ayat 3: "Pemerintah mengusahakan dan menyeleng- garakan satu sistem pendidikan nasional yang meningkatkan keimanan dan ketakwaan serta akhlak mulia dalam rangka mencerdaskan kehidupan bangsa, yang diatur dengan undang-undang".

$$
\text { Undang-Undang Republik }
$$

Indonesia Nomor 20 Tahun 2003 tentang Sistem Pendidikan Nasional.

Undang-Undang Republik

Indonesia Nomor 43 Tahun 2007 tentang Perpustakaan.

Undang-Undang Republik Indonesia Nomor 24 tahun 2009 tentang Bendera, Bahasa, dan Lambang Negara serta Lagu Kebangsaan.

Peraturan Pemerintah Republik Indonesia Nomor 32 Tahun 2013 tentang Perubahan Kedua atas Peraturan Pemerintah Republik Indonesia Nomor 19 tahun 2005 tentang Standar Nasional Pendidikan.
Peraturan Pemerintah Nomor 24 tahun 2014 tentang Pelaksanaan UU Nomor 43 Tahun 2007 tentang Perpustakaan

Peraturan Menteri Dalam Negeri Nomor 40 Tahun 2007 tentang Pedoman bagi Kepala Daerah dalam Pelestarian dan Pengembangan Bahasa Negara dan Bahasa Daerah.

Peraturan Menteri Pendidikan Nasional Nomor 24 tahun 2007 tentang Standar Sarana dan Prasarana untuk Sekolah Dasar/Madrasah Ibtidaiyah (SD/MI), Sekolah Menengah Pertama (SMP/MTs), dan Sekolah Menengah Atas/Madrasah Aliyah (SMA/MA).

Permendikbud Nomor 23 Tahun 2015 tentang Penumbuhan Budi Pekerti.

Permendikbud Nomor 12 Tahun 2018 tentang Perubahan atas Permendikbud Nomor 22 Tahun 2015 tentang Rencana Strategis Kementerian Pendidikan dan Kebudayaan Tahun 20152019.

Permendikbud Nomor 23 Tahun 2013 tentang Perubahan Permendikbud No. 15 Tahun 2010 tentang SPM Dikdas di Kabupaten/Kota.

Permendikbud Nomor 21 Tahun 2015 tentang Gerakan Pembudayaan Karakter di Sekolah.

Undang-Undang Republik

Indonesia Nomor 3 Tahun 2017 tentang Sistem Perbukuan.

Undang-Undang Republik

Indonesia Nomor 5 Tahun 2017 tentang Pemajuan Kebudayaan.

Permendikbud Nomor 26 Tahun 2017 tentang Perubahan atas Peraturan Menteri Pendidikan dan Kebudayaan Nomor 8 Tahun 2017 tentang Petunjuk 
Teknis Bantuan Operasional Sekolah (Kemendikbud Satgas Gerakan Literasi Sekolah, 2019, hlm. 4-5).

\section{Implementasi Gerakan Literasi Sekolah}

Dalam penerapan gerakan literasi sekolah mengacu pada buku panduan literasi sekolah sebagai payung hukum dan penjelasan detail mengenai gerakan literasi sekolah. Gerakan literasi sekolah memiliki buku panduan umum dan buku panduan khusus. Panduan umum bergaris besar petunjuk pelaksanaan literasi sekolah, sedangkan panduan khusus membahas petunjuk teknis penyelenggaraan literasi di tiap satuan pendidikan (Antoro, 2017, hlm. 16).

Berikut isi buku panduan khusus yang dapat digunakan sebagai acuan satuan lembaga pendidikan dalam melaksanakan program gerakan literasi sekolah: "Pembiasaan membaca di rumah Pelibatan orang tua dalam GLS,15 menit membaca, Pembentukan Tim Literasi Sekolah (TLS), Mengembangkan sudut baca di sekolah, Kelas kaya literasi, Pengembangan perpustakaan sekolah, Memilih buku bacaan yang baik, Bertanya tentang buku, Tiga langkah membaca buku fiksi, Tiga langkah membaca buku nonfiksi, Empat cara membaca, Membaca dalam hati, Jurnal membaca harian, Tabel tahu-ingin-pelajari, Pelibatan publik, Proposal untuk kegiatan GLS, Teka-teki literasi”.

Satuan lembaga pendidikan dalam mengimplementasikan program $\mathrm{k}$ literasi sekolah dapat mengacu pada buku yang poin-poinnya telah tercantum di atas, selain itu, dalam pelaksanaan program gerakan literasi sekolah diperlukan pembentukan tim literasi sekolah. Hal ini bertujuan untuk memastikan gerakan literasi sekolah dapat berjalan dengan baik. Para tim gerakan literasi sekolah juga memiliki struktur dan tugas masingmasing (Tim Satgas GLS, 2017).

Dikarenakan Indonesia menganut sistem otonomi daerah, maka kecil kemungkinannya untuk tidak berbeda program gerakan literasi yang masingmasing mereka programkan. Kepala sekolah memiliki otoritas besar untuk mengatur sekolah. Maka dari itu setiap daerah memiliki program yang berbedabeda dan setiap daerah dapat mengembangkan program-program dalam sekolahnya yang dapat menumbuhkan minat literasi masyarakat sekolahnya, baik guru, pendidik, peserta didik, hingga staf kependidikan dengan mengacu pada bukubuku panduan gerakan literasi.

\section{SIMPULAN}

Gerakan literasi sekolah merupakan sebuah upaya yang dilakukan secara menyeluruh dan berkelanjutan untuk menjadikan sekolah sebagai organisasi pembelajaran yang warganya literat sepanjang hayat melalui pelibatan publik. Pada awalnya literasi dipandang hanya sebagai kemampuan membaca dan menulis saja, namun lambat laun literasi menjadi luas pengertiannya menjadi perangkat ketrampilan literasi dalam keberagaman domain literasi yang dikenal dengan sebutan multi literasi.

Diadakannya suatu gerakan literasi sekolah pastilah memiliki tujuan, baik tujuan umum maupun tujuan khusus, salah satunya adalah menjadikan sekolah sebagai organisasi pembelajar yang berbudaya literasi. 
Dalam pembuatannya pun juga berlandaskan landasan filosofi dan banyak landasan hukum yang melatarbelakanginya. Dalam pengimplementasiannya gerakan literasi sekolah dapat ber-acukan pada buku-buku induk literasi yang telah di luncurkan sebagai payung hukum dan acuan lembaga-lembaga sekolah dalam pelaksanaan kegiatan literasi sekolah, karena pada dasarnya setiap daerah dalam pengimplementasian gerakan literasi sekolah berbeda-beda sesuai dengan kebijakan otonomi daerah.

\section{REFERENSI}

Antoro, B. (2017). Gerakan Literasi Sekolah. Jakarta: Direktorat Jenderal Pendidikan Dasar dan Menengah Kementerian Pendidikan dan Kebudayaan.

Fath, Z. Al, Sholina, A., Isma, F., \& Rahmawan, D. I. (2018). Kebijakan gerakan literasi sekolah (Konsep dan Implementasi). Abdau: Jurnal Pendidikan Madrasah Ibtidaiyah, 1(1), 339-353. https://doi.org/10.36768/abdau.v1i2. 19

Kemendikbud. (2015). Regulation of the Minister of Education and Culture of the Republic of Indonesia Number 23 of 2015 concerning Cultivation of Character. 1-8.

Kemendikbud Satgas Gerakan Literasi Sekolah. (2019). Desain Induk Gerakan Literasi Sekolah. Direktorat Jenderal Pendidikan Dasar dan Menengah Kementerian Pendidikan dan Kebudayaan.

Sari, I. F. R. (2018). Konsep Dasar Gerakan Literasi Sekolah Pada Permendikbud Nomor 23 Tahun 2015 Tentang Penumbuhan Budi Pekerti. Al-Bidayah: Jurnal Pendidikan Dasar Islam, 10(1), 89-
100. https://doi.org/10.14421/albidayah.v10i1.131

Tim Satgas GLS. (2017). Panduan Praktis Gerakan Literasi Sekolah. Direktorat Jenderal Pendidikan Dasar dan Menengah Kementrian Pendidikan dan Kebudayaan.

Zed, M. (2008). Metode Penelitian Kepustakaan. Yayasan Obor Indonesia. 